\title{
Resistant Priapism in Hemodialysis Patient: A Rare Case
}

\author{
Mustafa Gürkan Yenice, Yusuf Arıkan, Kamil Gökhan Şeker, Abdulmuttalip Şimsek, Volkan Tuğcu \\ Department of Urology, Bakirkoy Dr. Sadi Konuk Training and Research Hospital, Istanbul, Turkey
}

Cite this article as: Yenice MG, Arıkan Y, Şeker KG, Şimşek A, Tuğcu V. Resistant Priapism in Hemodialysis Patient: A Rare Case. J Emerg Med Case Rep 2018; 9: 47-50.

\begin{abstract}
Introduction: Priapism is a penis erection that lasts longer than 4 hours without sexual stimulation and is a urological emergency that requires immediate treatment.Priapism can be seen rarely after hemodialysis. We aimed to present the patient with resistant priapism who underwent hemodialysis.

Case Report: A 47-year-old man who underwent hemodialysis for two months due to end-stage renal disease admitted to the emergency department due to priapism. The penis was painful and rigid.Despite the drainaged of approximately 150 cc venous blood from corpus cavernosum with in 30 minutes,no detumescence was achieved. We performed a T-shunt combined with corporal tunneling.In the follow-up visits,the patient who was not able to have detumescence was informed and planned to have an early implantation of penile prosthesis due to necrosis, fibrosis,permanent loss of erection.

Conclusion: Mechanism of priapism in hemodialysis patient is accused of inadequate heparinization and dialysis-induced hypoxemia and acidosis. First line treatment for ischemic priapism in emergency department is very important.The patient should be intervened quickly and directed to the urologist.
\end{abstract}

Keywords: Priapism, hemodialysis, resistant priapism

Received: 18.09.2017 Accepted: 19.12.2017

\section{Introduction}

Priapism is a penis erection that lasts longer than $4 \mathrm{~h}$ without sexual stimulation and is a urological emergency that requires immediate intervention. The incidence of priapism is 15 per 100,000 males per year, and this pathological condition can occur at any age (1).

There are many risk factors in the etiology of priapism: alcohol and drug abuse, hematologic dyscrasias (thalassemia, thrombophilia, and sickle cell anemia), thrombotic disease (asplenia and erythropoietin use), trauma, hematologic malignancies, metastatic malignancies, intracavernous injections for erectile dysfunction, spinal cord injury, and use of certain oral antipsychotics and phosphodiesterase type 5 inhibitors (2).

Herein, we present a case of a 47-year-old man with persistent priapism who underwent hemodialysis.

\section{Case Report}

A 47-year-old man was admitted to the emergency department due to priapism with a painful erection starting at approximately $5 \mathrm{~h}$ after hemodialysis treatment and persisting for approximately $30 \mathrm{~h}$. The patient had undergone hemodialysis for 2 months due to end-stage renal disease. There was no history of trauma, sickle cell anemia, illegal drug use, nitrate use, sex- 


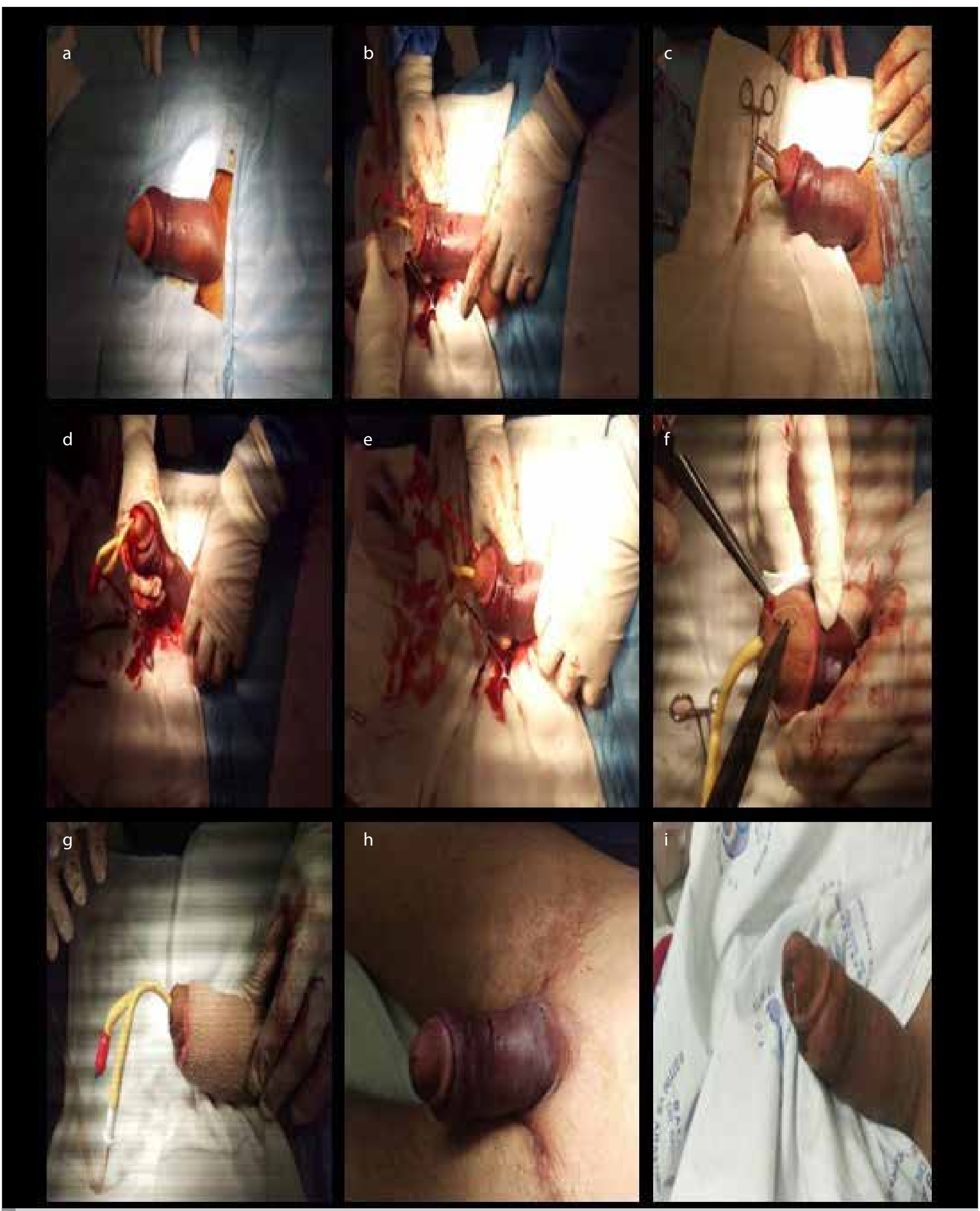

FIGURE 1a-i. Management of persistent priapism. (a) Appearance of a rigid penis. (b, c) Hegar dilators passing across the entire corporal body. (d, e) Milking maneuver and drainage of cavernosal blood. (f, g) Surgical closure of incision lines in the glans penis. (h) Appearance at postoperative day 1. (i) Appearance at postoperative week 1. 
ual intercourse, any psychostimulant use, and vasoactive agent or phosphodiesterase inhibitor use. The penis was painful and rigid. Laboratory examination revealed blood urea nitrogen (BUN) BUN: $89 \mathrm{mg} / \mathrm{dL}, \mathrm{Cr}: 6.23 \mathrm{mg} / \mathrm{dL}$, and Hb: $10.8 \mathrm{~g} / \mathrm{dL}$, and blood gas analysis of blood from the corpus cavernosum revealed $\mathrm{pH}: 7.3, \mathrm{pCO}_{2}$ : $49.1 \mathrm{mmHg}$, and $\mathrm{pO}_{2}: 51 \mathrm{mmHg}$. The patient was diagnosed with ischemic priapism. The patient had subsequently undergone a failed conservative management, which involved multiple corporal aspiration with a 16-G butterfly needle. Intracavernous injection of sympathomimetic phenylephrine up to $1,000 \mathrm{mg}$ in aliquots of 200-250 mg was administered to the patient under local anesthesia (penile block). Despite the removal of approximately 150 cc venous blood within 30 min, no detumescence was achieved (Figure 1a). We decided to perform a T-shunt combined with corporal tunneling. A small incision was made in the glans penis, and an Surgical Scalpel Blade No.11P. Swann-Morton Ltd 11 blade was passed from the spongy glandular tissue into the corpora. We passed sequential Hegar dilators bilaterally across the entire corporal body (Figures $1 \mathrm{~b}$ and $1 \mathrm{c}$ ). During the procedure, a urethral catheter was placed to avoid urethral injury. The penis was manually manipulated (milking maneuver), and blood in the corpus cavernosa was drained (Figures $1 \mathrm{~d}$ and 1e). Afterwards, the incision lines in the glans penis were closed with a 3.0 polyglactin 910 suture (Figure 1f). The penis was wrapped with a bandage (Figure $1 \mathrm{~g}$ ). In the follow-up visits, it was found that the patient was unable to achieve penile detumescence (Figures $1 \mathrm{~h}$ and $1 \mathrm{i}$ ). We planned to perform early implantation of a penile prosthesis due to necrosis, fibrosis, and permanent loss of erection. The patient was informed about his results, and written consent for publishing this case report was obtained.

\section{Discussion}

Priapism is divided into three main types: ischemic, non-ischemic, and stuttering (3). Ischemic priapism accounts for 95\% of all cases; it is the most common type and is an urological emergency (2). Ischemic priapism is a persistent erection in which there is little or no arterial inflow to the corpus cavernosum. Progressive hypoxia, hypercarbia, and acidosis was observed together with time-dependent changes in the corporal metabolic environment. Immediate intervention is required for penile compartment syndrome. Therefore, if timely intervention is not provided, permanent tissue damage can occur (4). Herein, the patient was diagnosed with ischemic persistent priapism with hypoxia, hypercarbia, and acidosis in the blood gas from the corpus cavernosum.

Previous studies have reported priapism during or after hemodialysis caused by several etiological factors: (a) inadequate heparinization, (b) sickle cell disease (2), (c) the process of dysregulation at the penile tissue level, and (d) dialysis-induced acidosis and hypoxemia (5-7). Conversely, heparin-induced priapism is a special type of pharmacologically induced prolonged erection, but its pathophysiological principles remain unclear. Heparin-induced platelet antibodies can lead to the accumulation of platelets, thereby obstructing the flow of penile blood, resulting in low-flow priapism. Alternatively, this can be explained by the initial high-flow priapism, which later transforms into ischemic priapism. The question is whether hemor- rhage with subsequent organisation of the hematoma and late fibrosis constitutes a pathogenetic factor. It remains unclear whether hematoma and late fibrosis are regulated by hemorrhage or whether it is a pathogenetic factor for bleeding (8). The dialysis program for our patient was occasionally performed without the use of heparin; thus, we thought that priapism occurred due to insufficient heparinization and dialysis-induced acidosis and hypoxemia.

Given the severity of this consequence, early recognition of the situation and prompt management are important. Ischemic priapism is typically managed with first-line treatments, including blood aspiration and intracavernosal sympathomimetic drug injections, by intracavernous injection of an alpha-adrenergic agent, such as diluted phenylephrine, in the first $24 \mathrm{~h}$ (9). Patients can be saved from an invasive intervention particularly if they respond to the administration of symptomatic medications (such as terbutaline, salbutamol, and pseudoephedrine) during the first intervention in the emergency room (10).

Surgical intervention is usually necessary for patients who fail conservative treatment after 24 hours. Typically, a distal shunt between the corpus cavernosum and the glans penis is created using a percutaneous procedure (Ebbehoj or Winter, T-shunt) or an open (AlGhorab) procedure in second-line treatment (9). A T-shunt combined with corporal tunneling is currently the most popular surgery (3). In our case, we performed a T-shunt procedure with corporal tunneling.

Immediate implantation of a penile prosthesis is recommended for patients who present 48-72 h after the onset of a priapism episode (2). Early implantation 2 weeks after ischemic priapism causes early postoperative complications such as erosion or infection; delaying implantation for 2 months or more can cause patients to generally encounter more satisfaction and less penile shortening (11). In our case, the treatment protocols were progressively performed, but the patient could not achieve detumescence. Therefore, we suggested implantation of a penile prosthesis.

\section{Conclusion}

Priapism is a urological emergency and can be observed in rare cases after hemodialysis. The mechanism of priapism in our hemodialysis patient is suggested to be inadequate heparinization and dialysis-induced hypoxemia and acidosis. Priapism causes erectile dysfunction if not treated early. First-line treatment for priapism in the emergency department is very important. However, there is a need for more advanced studies due to lack of sufficient cases.

Informed Consent: Written informed consent was obtained from patients who participated in this study.

Peer-review: Externally peer-reviewed.

Author Contributions: Concept - M.G.Y., Y.A.; Design - Y.A., K.G.S.; Supervision A.S.,V.T.; Resources - M.G.Y., Y.A., K.G.S.; Materials - Y.A., K.G.S.; Data Collection and/ or Processing - A.S., Y.A.; Analysis and/or Interpretation - M.G.Y., V.T.; Literature Search - Y.A., K.G.S.; Writing Manuscript - Y.A., K.G.S., M.G.Y.; Critical Review - A.S., V.T. 
Conflict of Interest: The authors have no conflict of interest to declare.

Financial Disclosure: The authors declared that this study has received no financial support.

\section{References}

1. Salonia A, Eardley I, Giuliano F, Hatzichristou D, Moncada I, Vardi Y, et al. European Association of Urology guidelines on priapism. Eur Urol 2014; 65: 480-9. [CrossRef]

2. Yücel ÖB, Salabaş E, Ermeç B, Kadıoğlu A. The case report of priapus and a modern approach to an ancient affliction. Sex Med Rev 2017; 5: 120-8. [CrossRef]

3. Montague DK, Jarow J, Broderick GA, Dmochowski RR, Heaton JP, Lue $\mathrm{TF}$, et al. American Urological Association guideline on the management of priapism. J Urol 2003; 170: 1318-24. [CrossRef]

4. Kalathia J, Agrawal S, Chipde SS, Agrawal R. Homocysteinemia: A rare cause of priapism. Urol Ann 2016; 8: 118-21. [CrossRef]

5. Port FK, Fiegel P, Hecking E, Kohler H,Distler A. Priapism during regular haemodialysis. Lancet 1974; 2:1287-8. [CrossRef]
6. Fassbinder W, Frei U, Issantier R, Koch KM, Mion C, Shaldon S, et al. Factors predisposing to priapism in haemodialysis patients. Proc Eur Dial Transplant Assoc 1976; 12: 380-6.

7. Singhal PC, Lynn Rl, Scharschmidt LA. Priapism and dialysis. Am J Nephrol 1986; 6: 358-61. [CrossRef]

8. Bschleipfer TH, Hauck EW, Diemer TH, Bitzer M, Kirkpatrick Ch J, Pust RA, et al. Heparin-induced priapism. Int J Impot Res 2001; 13: 357-9. [CrossRef]

9. Kovac JR, Mak SK, Garcia MM, Lue TF. A pathophysiologybased approach to the management of early priapism. Asian J Androl 2013; 15: 20-6. [CrossRef]

10. Sonmez MG, Sonmez LO, Taskapu HH, Kara C, Dundar ZD, Goger TE, et al. Etiological factors and management in priapism patients and attitude of emergency physicians. Arch Ital Urol Androl 2017; 89: 203-7. [CrossRef]

11. Zacharakis E, Garaffa G, Raheem AA, Christopher AN, Muneer A, Ralph DJ. Penile prosthesis insertion in patients with refractory ischaemic priapism: early vs delayed implantation. BJU Int 2014; 114: 576-81. [CrossRef] 